Dikirim: 30 Juli 2017 Diterbitkan: 15 Maret 2018

\section{Determinan beban pengasuh pasien stroke pasca perawatan di rumah sakit di RSUD dr. Soediran Mangun Sumarso, Wonogiri}

Determinants caregiver burden of stroke patients after hospitalization in dr. Soediran Mangun Sumarso Hospital, Wonogiri

Sri Nurjannah ${ }^{1} \&$ Ismail Setyopranoto ${ }^{2}$

\begin{abstract}
Purpose: The purpose of this study was to explore the factors associated with caregiver burden on primary caregivers of stroke patients after treatment in dr. Mangun Soediran Sumarso Wonogiri hospital. Method: Observational research used cross-sectional study approach. The study was conducted in Wonogiri district involving 206 caregivers of stroke patients. Subjects were taken consecutively from those who met the eligibility criteria. Measurement of caregiver burden used Zarit Burden Interview (ZBI). Analysis used Poisson Regression. Results: The results showed that there were $40.78 \%$ caregivers experiencing caregiver burden. Patients who had a total dependence (PR 1.86; 95\% Cl 1021-3377), severe (PR 1.77; 95\% Cl 1026-3068), moderate (PR 2:08; 95\% Cl 1167-3710) and the duration of care for patients $>6$ hours / day were significant factors affecting the caregiver burden on primary caregivers of stroke patients. Conclusion: Caregivers burden is influenced by patient's condition and care duration of patients. Education related to homecare for caregivers before patient was out from the hospital was needed as well as conducted regular consultations for the caregivers
\end{abstract}

Keywords: caregiver burden; stroke patients; home care

\footnotetext{
${ }^{1}$ Departemen Biostatistik, Epidemiologi, dan Kesehatan Populasi, Fakultas Kedokteran,Kesehatan Masyarakat dan Keperawatan, Universitas Gadjah Mada. (Email: srinurjannah@ymail.com)

${ }^{2}$ Departemen Ilmu Penyakit Saraf, Fakultas Kedokteran, Kesehatan Masyarakat dan Keperawatan, Universitas Gadjah Mada
} 


\section{PENDAHULUAN}

World Health Organization (WHO) menyatakan bahwa ada 15 juta penderita stroke di dunia tiap setiap tahun, dan dari jumlah tersebut sekitar lima juta orang meninggal dan lima juta lainnya cacat permanen. Situasi stroke di dunia tidak jauh berbeda dengan situasi stroke di Indonesia, dimana penyakit stroke menjadi salah satu penyebab kematian tertinggi dan penyebab kecacatan nomor satu. Prevalensi stroke di Jawa Tengah sebesar 7,7\% (1), sedangkan jumlah penderita stroke di Kabupaten Wonogiri sekitar 777 orang di tahun 2015. Kasus stroke di Wonogiri menduduki peringkat ketiga tertinggi di provinsi Jawa Tengah setelah Salatiga dan Boyolali. Stroke menempati peringkat kedua sebagai penyakit penyebab kematian tertinggi di Kabupaten Wonogiri setelah hipertensi (2).

Penyakit stroke memberikan beban ganda baik untuk penderita maupun untuk keluarga. Pada penderita, serangan stroke dapat berdampak pada penurunan fungsi gerak tubuh yang yang menimbulkan ketidakmandirian penderita untuk melakukan aktivitas seperti biasa, baik di lingkungan rumah maupun di lingkungan masyarakat. Aktivitas penderita stroke akan banyak dihabiskan di lingkungan rumah maka peran keluarga sangat besar dalam pengasuhan pasien stroke pasca serangan dibanding peran petugas kesehatan.

Stroke menyebabkan kelumpuhan, gangguan daya pikir, gangguan kesadaran, perubahan mental, penurunan konsentrasi, kemampuan belajar dan fungsi intelektual lainnya, stroke bahkan menyebabkan gangguan komunikasi dan gangguan emosional yang diperparah dengan kurang persiapan dan pengetahuan dalam merawat pasien stroke. Pengasuh kemungkinan mengalami efek buruk pada kesehatan fisik dan emosional, gangguan pada kegiatan sosial, dan situasi keuangan yang memburuk, hal ini disebut "caregivers burden".

Penelitian menemukan 50\% pengasuh pasien stroke mengalami gejala beban ringan, $47,3 \%$ sedang dan $1,2 \%$ berat. Faktor yang paling berhubungan dengan beban pengasuh adalah kedekatan hubungan dengan pasien, jumlah pengasuh, durasi menderita stroke dan durasi merawat pasien per hari (3). Faktor yang berhubungan dengan peningkatan depresi pada pengasuh utama adalah tingkat keparahan penderita, ketergantungan penderita (4), sikap dari penderita, hilangnya fungsi keluarga, dan status hubungan dengan pasien (5).
Penelitian terkait beban pengasuh, depresi dan stres pada pengasuh utama pasien stroke masih sangat jarang dilakukan di Indonesia. Penelitian masih berfokus pada pasien stroke sehingga teori terkait pengasuh masih mengadopsi dari penelitian yang dilakukan di luar negeri dimana kondisi dari pengasuh pasien stroke dianggap suatu isu yang penting dari dampak mengasuh pasien stroke (5). Oleh sebab itu penelitian terkait beban pengasuh perlu dilakukan.

Penelitian ini bertujuan untuk mengetahui faktor deteminan caregiver burden pada pengasuh utama pasien stroke pasca perawatan di RSUD dr. Soediran Mangun Sumarso Kabupaten Wonogiri.

\section{METODE}

Penelitian cross-sectional dilakukan di Kabupaten Wonogiri pada bulan April-Juni 2017. Sampel adalah pengasuh utama pasien stroke yang pernah menjalani perawatan atau pengobatan. Kriteria inklusi adalah pasien stroke,tidak memiliki penyakit kecacatan lain sebelum stroke, orang yang independen sebelum menderita stroke. Kriteria pengasuh adalah mengasuh langsung pasien stroke minimal satu bulan setelah serangan, tidak sedang mengasuh pasien lain dalam waktu yang panjang dan bersamaan.

Subjek penelitian diambil secara consecutive dari mereka yang memenuhi kriteria. Besar sampel dihitung menggunakan sample size software. Dari hasil penghitungan diperoleh jumlah sampel minimal sebanyak 187 di tambah 10\% untuk respon rate menjadi 206 sampel. Variabel terikat dalam penelitian ini adalah beban pada pengasuh utama pasien stroke, sedangkan variabel bebas dalam penelitian ini adalah umur pasien, jenis kelamin pasien, umur pengasuh, jenis kelamin pengasuh, pendidikan pengasuh, jumlah serangan, ADL, jumlah pengasuh, status kekeluargaan dan durasi mengasuh.

Kuesioner Zarit burden Interview digunakan untuk mengukur status fungsional dasar atau ketergantungan pasien stroke dalam melakukan kegiatan rutin seharihari. Analisis data dilakukan dengan menggunakan uji chi-square dan poisson regression dengan tingkat signifikansi $\alpha=0,05$. Penelitian ini telah mendapatkan kelayakan penelitian dari Komisi Etik Penelitian FK UGM.

\section{HASIL}

Tabel 1 menunjukkan ciri dan hubungan pengasuh utama dan penderita stroke menurut kelompok yang memiliki dan yang tidak memiliki beban pengasuh. 
Empat puluh satu persen pengasuh utama pasien stroke mengalami beban atau caregivers burden. Mayoritas pengasuh utama adalah wanita dan lulusan sekolah dasar dan sekolah menengah atas. Sebagian besar pengasuh tidak bekerja (41.75\%), petani sebesar $27.67 \%$ sedangkan terendah adalah pensiunan dan pegawai pemerintah. Dalam melakukan perawatan lebih dari 50\% pengasuh memiliki pengasuh alternatif yang ikut membantu dengan durasi merawat lebih banyak pada durasi < 6 jam/hari. Mayoritas pasien berjenis kelamin laki-laki dan berumur 55-68 tahun. Pasien stroke didominasi pasien dengan serangan pertama. Berdasarkan activity daily living pasien stroke sebagian besar memiliki ketergantungan ringan.

Tabel 1. Ciri dan hubungan pengasuh utama dan pasien stroke

\begin{tabular}{|c|c|c|c|}
\hline \multirow{2}{*}{ Variabel } & \multicolumn{2}{|c|}{ Beban pengasuh } & \multirow{2}{*}{ PR (95\% CI) } \\
\hline & Ada & Tidak & \\
\hline \multicolumn{4}{|l|}{ Ciri pasien stroke } \\
\hline Jenis kelamin & & & $1.1(0.80-1.56)$ \\
\hline Perempuan & 38 & 61 & \\
\hline Laki-laki & 46 & 61 & \\
\hline Umur & \multicolumn{2}{|c|}{$\begin{array}{c}\text { Mean } \pm \text { SD } \\
66.56 \pm 9.77\end{array}$} & $0.9(0.9-1.01)$ \\
\hline \multicolumn{4}{|l|}{ Serangan } \\
\hline Pertama & 53 & 86 & $1.2(0.8-1.7)$ \\
\hline Berulang & 31 & 36 & \\
\hline \multicolumn{4}{|l|}{ ADL } \\
\hline Total & 19 & 14 & $2.9^{* * *}(1.6-5.0)$ \\
\hline Berat & 33 & 32 & $2.5^{* *}(1.5-4.3)$ \\
\hline Sedang & 18 & 20 & $2.4^{* *}(1.3-4.2)$ \\
\hline Ringan & 14 & 56 & 1 \\
\hline \multicolumn{4}{|l|}{ Status pekerjaan } \\
\hline Bekerja & 10 & 27 & $1.6(0.9-2.8)$ \\
\hline Berhenti & 74 & 95 & \\
\hline \multicolumn{4}{|c|}{ Ciri pengasuh utama } \\
\hline \multicolumn{4}{|c|}{ Kelamin } \\
\hline Wanita & 66 & 96 & $0.9(0.7-1.5)$ \\
\hline Laki-laki & 18 & 26 & \\
\hline Umur & \multicolumn{2}{|c|}{ Mean \pm SD } & $1.0(0.9-1.0)$ \\
\hline \multicolumn{4}{|l|}{ Pendidikan } \\
\hline Rendah & 59 & 72 & $1.4(0.9-1.9)$ \\
\hline Tinggi & 25 & 50 & \\
\hline \multicolumn{4}{|c|}{ Pengasuh alternatif } \\
\hline \multirow[t]{2}{*}{ Tidak ada } & 50 & 84 & $1.3(0.9-1.8)$ \\
\hline & 34 & 38 & \\
\hline \multicolumn{4}{|l|}{ Status } \\
\hline Istri & 35 & 40 & $1.2(0.9-1.7)$ \\
\hline Bukan istri & 49 & 82 & \\
\hline Durasi merawat & & & $2.5(1.7-3.5)$ \\
\hline$\leq 6 \mathrm{jam} / \mathrm{hari}$ & 31 & 91 & \\
\hline > 6 jam/hari & 53 & 31 & \\
\hline
\end{tabular}

Hasil uji statistik menunjukkan bahwa jenis kelamin, umur, pendidikan, pengasuh alternatif dan hubungan kekeluargaan tidak berhubungan signifikan dengan beban pengasuh. Prevalensi beban pengasuh perempuan 0.98 kali lebih besar dibanding dengan pengasuh laki-laki (PR 0.99; 95\% CI 0.667-1.486), namun secara statistik tidak bermakna ( $p$-value 0.983). Prevalensi beban pengasuh berpendidikan rendah 1.35 kali lebih besar dibanding prevalensi pengasuh berpendidikan tinggi, walaupun hubungan ini tidak bermakna secara statistik ( $p$-value 0.1000 ).

Prevalensi beban pengasuh 1.27 kali lebih besar pada pengasuh tunggal dibanding dengan pengasuh yang memiliki dukungan pengasuh alternatif, namun tidak bermakna secara statistik ( $p$-value 0.100). Prevalensi beban pengasuh yang berstatus istri 1.25 kali lebih besar dibanding dengan prevalensi pengasuh yang bukan berstatus istri, walaupun hubungan ini tidak bermakna secara statistik (PR 1.25; 95\% CI 0.898-1.731).

Penelitian menemukan prevalensi beban pengasuh pada pengasuh yang merawat pasien lebih dari 6 jam per hari 2,5 kali lebih besar dibanding dengan prevalensi beban pengasuh pada pengasuh yang merawat pasien stroke kurang dari 6 jam per hari ( $p$-value 0.000). Beban terjadi bukan hanya akibat faktor dari pengasuh.

Penelitian ini menemukan bahwa jenis kelamin pasien, umur dan jumlah serangan tidak berhubungan dengan beban pengasuh, namun activity daily living pasien stroke berhubungan signifikan dengan beban pengasuh. Prevalensi beban pengasuh pada pengasuh yang merawat pasien stroke dengan ketergatungan total 2.88 kali lebih besar dibanding dengan prevalensi pengasuh yang merawat pasien stroke dengan ketergantungan ringan. Prevalesi beban pengasuh 2.54 kali lebih besar pada pengasuh yang merawat pasien stroke dengan ketergantungan berat dibanding dengan penga- suh yang merawat pasien dengan ketergantungan ringan. Prevalensi beban pengasuh pada pengasuh yang merawat pasien stroke dengan ketergantungan sedang 2.4 kali lebih besar dibanding dengan preva- lensi beban pengasuh pada pengasuh pasien stroke ketergantungan ringan.

Tabel 2 menunjukkan prevalensi beban pengasuh 1.8 kali lebih besar pada pengasuh yang merawat pasien stroke dengan keterbatasan total dibanding, pre- valensi beban pengasuh pada pengasuh pasien stroke dengan ketergantungan berat 1.7 kali lebih besar dibanding prevalensi beban pengasuh pada pengasuh pasien stroke ketergantungan ringan. 
Tabel 2. Hasil Analisis Multivariabel

\begin{tabular}{|c|c|c|c|c|c|}
\hline Variabel & Model 1 & Model 2 & Model 3 & Model 4 & Model 5 \\
\hline Umur caregiver & $1(0.989-1.016)$ & $1(0.990-1.017)$ & & & \\
\hline Pendidikan caregiver & $1.04(0.730-1.497)$ & & & & \\
\hline ADL & & & & & \\
\hline Ketergantungan total & $2.04(1.099-3.787)^{*}$ & $2.04(1.103-3.790) *$ & $2.03(1.094-3.784)^{*}$ & $1.92(1.050-3.523)^{*}$ & $1.86(1.021-3.377)^{*}$ \\
\hline $\begin{array}{l}\text { Ketergantungan } \\
\text { berat }\end{array}$ & $1.87(1.056-3.297)^{*}$ & $1.87(1.063-3.303)^{*}$ & $1.88(1.063-3.329)^{*}$ & $1.79(1.022-3.136)^{*}$ & $1.77(1.026-3.068)^{*}$ \\
\hline $\begin{array}{l}\text { Ketergantungan } \\
\text { sedang }\end{array}$ & $2.19(1.227-3.924)^{* *}$ & $2.20(1.235-3.928)^{* *}$ & $2.21(1.236-3.949)^{* *}$ & $2.14(1.202-3.813)^{* *}$ & $2.08(1.167-3.710)^{*}$ \\
\hline $\begin{array}{l}\text { Ketergantungan } \\
\text { ringan }\end{array}$ & Ref & Ref & Ref & Ref & Ref \\
\hline Caregiver alternatif & $1.20(0.862-1.680)$ & $1.21(0.864-1.684)$ & $1.21(0.866-1.696)$ & & \\
\hline Status kekeluargaan & $1.19(0.832-1.703)$ & $1.20(0.839-1.709)$ & $1.24(0.889-1.720)$ & $1.32(0.982-1.783)$ & \\
\hline Durasi merawat & $1.96(1.321-2.919)^{* * *}$ & $1.97(1.329-2.924)^{* * *}$ & $1.98(1.329-2.944)^{* * *}$ & $2.06(1.400-3.041)^{* * *}$ & $2.09(1.428-3.048)^{* * *}$ \\
\hline$\overline{\mathrm{BIC}}$ & 342.46263 & 337.16406 & 331.98989 & 327.26827 & 323.50027 \\
\hline
\end{tabular}

\section{BAHASAN}

Penelitian ini tidak menemukan perbedaan rata-rata umur pasien antara pengasuh yang memiliki beban dan tidak memiliki beban. Hal ini terjadi karena distribusi beban pengasuh pada semua kategori umur lebih banyak pada kategori tidak ada beban dibanding ada beban. Penelitian ini didukung penelitian lain yang menyatakan bahwa umur pasien tidak memiliki hubungan dengan tingkat beban pengasuh $(6,7)$.

Penelitian tidak menemukan hubungan signifikan jenis kelamin pasien dengan beban pengasuh pada pasien stroke karena distribusi jenis kelamin baik pada laki-laki maupun pada perempuan lebih banyak pada kelompok tidak ada beban. Penelitian ini sejalan dengan penelitian sebelumnya yang menyatakan bahwa tidak ada hubungan antara jenis kelamin dengan beban pengasuh pasien stroke (7).

Rata-rata umur pengasuh adalah 51 tahun. Hasil penelitian ini menemukan bahwa tidak ada perbedaan rata-rata umur pengasuh dengan beban pengasuh. Penelitian terdahulu menemukan bahwa tidak ada hubungan antara umur pengasuh dengan beban pengasuh pada pasien stroke (8). Namun, penelitian lain menunjukkan bahwa pengasuh umur >35 tahun berhubungan dengan beban pengasuh (6).

Berdasarkan uji bivariat jenis kelamin caregiver juga tidak ada hubungan dengan beban pengasuh. Hal ini terjadi karena persentase jenis kelamin pengasuh antara yang memiliki beban dan tidak memiliki beban cenderung sama. Hasil penelitian ini sejalan dengan penelitian Caleb Ademola yang menemukan bahwa tidak ada hubungan signifikan antara jenis kelamin caregiver dengan burden yang mereka alami (9). Namun hal ini kontra dengan penelitian yang dilakukan oleh Bhattacharjee yang menyatakan bahwa umur muda di bawah 45 tahun adalah faktor risiko untuk meningkatkan caregiver burden (10).
Pada karakteristik pengasuh, selain umur dan jenis kelamin, analisis juga dilakukan pada tingkat pendidikan. Pada penelitian ini, hasil menunjukkan bahwa tidak ada hubungan signifikan antara tingkat pendidikan dengan terjadinya beban pengasuh. Pada distribusi data pendidikan tinggi ataupun pendidikan rendah lebih banyak pada kategori tidak ada beban. Hasil ini serupa dengan penelitian yang dilakukan di Korea Selatan yang menemukan tingkat pendidikan tidak berhubungan dengan beban pengasuh pasien stroke (7).

Pada penelitian ini angka serangan tidak berhubungan signifikan dengan caregiver burden. Hasil dari penelitian ini tidak sejelan dengan penelitian yang dilakukan oleh Yuan li Gou di China yang menyatakan bahwa stroke berulang memiliki hubungan signifikan dengan tingginya tingkat depresi pada caregiver pasien stroke. Pada penelitian tersebut serangan berulang menyebabkan kondisi pasien stroke semakin memburuk dengan tingkat ketergantungan yang juga semakin memburuk dibanding dengan serangan pertama. Namun berbeda dengan penelitian ini dimana pasien stroke banyak yang telah mengalami ketergantungan berat (29.20\%) dan total (10.22\%) pada sengan stroke pertama.

Analisis bivariat menemukan bahwa tidak ada hubungan bermakna antara jumlah pengasuh dengan caregiver burden. Hal ini sejalan dengan penelitian yang dilakukan oleh Bhattacharjee yang menyatakan bahwa keberadaan pengasuh tambahan tidak berdampak pada caregiver burden. Namun, berbeda dengan penelitian lain yang menemukan terdapat hubungan jumlah pengasuh dengan caregiver burden. Pada peneitian ini jumlah pengasuh tidak berhubungan, kemungkinan dipengaruhi oleh caregiver aternatif tidak menetap di rumah yang sama dengan pasien atau pembagian tugas antara caregiver utama dengan caregiver alternatif yang tidak merata. 
Hasil dari penelitian ini menemukan bahwa tidak ada hubungan antara status kekeluargaan dengan caregiver burden. Hal ini berarti bahwa tidak ada hubungan antara istri dan bukan istri terhadap caregiver burden. Penelitian ini sejalan dengan penelitian McCullagh yang menyatakan bahwa tidak ada hubungan antara caregiver burden dengan hubungan kekeluargaan (8). Namun kontra dengan penelitian Caleb Ademola Gbiri yang menyatakan bahwa status kekeluargaan memiliki hubungan dengan caregiver burden pada pengasuh pasien stroke. begitupun dengan penelitian yang dilakukan oleh Choi Kwon Smi yang menemukan bahwa menantu lebih berpeluang untuk mengalami depresi dibanding suami-istri, anak dan orang tua (7).

Dari hasil penelitian ini ADL pasien memiliki hubungan bermakna dengan caregiver burden pada pengasuh utama pasien stroke. Penelitian ini sejalan dengan penelitian yang dilakukan oleh Yuan Li Gou (2015) yang menemukan bahwa ADL memiliki korelasi negatif dengan depresi pada caregiver dengan kekuatan korelasi 57.2\% dan OR 0.56. Hal ini berarti bahwa setiap peningkatan 1 score ADL berisiko 44\% lebih rendah untuk mengalami depresi. Penelitian yang dilakukan oleh Michael O menyatakan bahwa rendahnya status fungsional dari pasien stroke (ADL) berhubungan dengan tingginya tingkat burden pada caregiver (6).

Terdapat beberapa faktor yang dapat menjadi penyebab ADL sebagai faktor risiko terjadinya burden pada pengasuh utama pasien stroke. Jika pasien stroke mengalami ketergantungan pada orang lain maka pasien tersebut membutuhkan seorang caregiver yang dapat merawat mereka dalam keseharian. Perbedaan tingkat ADL juga akan memengaruhi durasi dalam merawat pasien tersebut. Dalam beberapa penelitian telah mengungkapkan bahwa orang yang merawat pasien lebih dari enam jam per hari akan berisiko mengalami burden. Activity daily living berhubungan dengan kemampuan gerak atau keparahan dari seorang pasien stroke. Sehingga caregiver akan membantu aktivitas sehari-hari dari pasien misalnya memindahkan posisi pasien, memandikan memberi makan. Hal ini dapat menimbulkan efek negatif pada tubuh caregiver. Terdapat beberapa caregiver yang mengeluhkan lengan atau pinggang yang sakit akibat mengangkat pasien.

Jika pasien memiliki keterbatasan gerak atau memiliki ketergantungan dengan orang lain maka secara otomatis tidak bisa bekerja sehingga tidak ada pemasukan keluarga. Pada penelitian ini sebagian besar penderita adalah laki-laki, dimana laki-laki sering kali dihubungkan dengan tulang punggung keluarga, orang yang memberikan kehidupan ekonomi bagi keluarga. Jika tidak bekerja maka tidak ada pemasukan, tidak ada pemasukan maka kebutuhan sehari hari akan sangat sulit terpenuhi diperparah dengan kebutuhan perawatan pasien stroke yang menghabiskan biaya yang tidak sedikit. Terbukti dengan persentase pasien stroke yang berhenti bekerja setelah mengalami serangan stroke sebesar 86.52\%. Hal ini yang menjadikan ADL sebagai salah satu faktor risiko caregiver burden.

Masalah ADL tidak hanya ketidak mampuan pasien dalam bekerja atau menghasilkan materi, namun isu pengalihan peran juga menjadi dampak dari buruknya tingkat keparahan dari pasien stroke. Seorang istri menggantikan posisi suami untuk mencari nafkah tanpa mengurangi peran mereka sebagai ibu rumah tangga. Dalam beberapa kasus dilema terjadi pada caregiver dimana mereka tidak bisa meninggalkan keluarga mereka (pasien stroke) dirumah tanpa pengawasan orang lain karena adanya kekhawatiran dengan kondisi pasien. Namun, disisi lain jika mereka hanya mengurus pasien di rumah, kecukupan dari segi ekonomi tidak akan terpenuhi. Sehingga dapat dikatakan bahwa seorang caregiver bisa mengalami double burden jika hal ini terjadi. Mereka akan mengalami beban dari segi fisik yang disebabkan oleh merawat pasien dan burden dari segi ekonomi karena tidak adanya pemasukan keluarga.

Persentase durasi merawat pasien stroke terbanyak pada kelompok ada beban adalah >6 jam/hari (63.10\%) dan pada kelompok tidak ada beban lebih banyak pada durasi <6 jam/hari (74.59). Dari hasil analisis multivariabel durasi merawat memiliki hubungan signifikan dengan caregiver burden (PR 2.09; 95\% CI 1.428-3.048). Hal tersebut berarti bahwa caregiver yang mengasuh pasien stroke $>6$ jam/hari memiliki risiko 2.09 kali lebih besar untuk mengalami burden dibanding dengan caregiver yang mengasuh pasien stroke $<6$ jam/hari.

Hasil penelitian ini sejalan dengan hasil penelitian yang dilakukan di Nigeria oleh Caleb Ademola Gbiri. Dalam penelitian tersebut menyatakan bahwa terdapat hubungan yang signifikan antara durasi merawat dengan caregiver burden. Korelasi dari kedua variabel tersebut adalah korelasi positif yang berarti bahwa semakin lama durasi caregiver merawat pasien stroke maka semakin tinggi beban yang dialami oleh caregiver dengan nilai rho=0.33 yang berarti bahwa kekuatan korelasi rendah (9). Begitupun dengan penelitian yang dilakukan oleh Krystyna Jaracz di Poland yang menemukan bahwa durasi merawat 
pasien berhu- bungan dengan caregiver burden pada pengasuh utama yang telah mengasuh pasien stroke selama 6 bulan. Namun, pada 5 tahun pasca stroke durasi merawat tidak berhubungan dengan caregiver burden (5).

Seorang yang merawat pasien stroke $>6$ jam perhari akan mudah mengalami rasa lelah dan jenuh. Seseorang tidak dapat memenuhi kebutuhan akan hiburan, bersosialisasi dengan teman, keluarga atau sekitar akibat tanggung jawab merawat pasien. Durasi merawat juga sering kali dikaitkan dengan jumlah caregiver yang merawat pasien stroke. Jika seorang caregiver memiliki bantuan orang lain dalam merawat pasien maka durasi mereka dalam merawat pasien stroke bisa dibagi. Namun jika mereka merupakan caregiver tunggal maka durasi merawat akan lebih besar. Hal ini menjadi faktor determinan terjadi burden pada caregiver.

\section{SIMPULAN}

Faktor determinan caregiver burden pada pengasuh utama pasien stroke adalah activity daily living pasien stroke dan durasi merawat pasien stroke. Tenaga kesehatan di RSUD dr. Soediran Mangun Sumarso Kabupaten Wonogiri diharapkan memberikan training atau edukasi terkait home care kepada caregiver sebelum pasien keluar dari rumah sakit. Jika memungkinkan dinas kesehatan sebaiknya membuat program rehabilitasi dan konsultasi yang melibatkan pasien dan caregiver dari pasien stroke.

\footnotetext{
Abstrak

Tujuan: Penelitian ini bertujuan mengetahui faktor-faktor yang berhubungan dengan caregiver burden pada pengasuh utama pasien stroke pasca perawatan. Metode: Penelitian ini merupakan penelitian observasional dengan pendekatan cross sectional. Penelitian dilakukan di Kabupaten Wonogiri. Sampel adalah Pengasuh utama pasien stroke minimal satu bulan setelah serangan. Pengumpulan data dilaksanakan pada bulan April-Juni 2017. Jumlah sampel minimal sebanyak 206. Subjek penelitian diambil secara consecutive dari mereka yang memenuhi kriteria pemasukan (eligibillity criteria). Pengukuran caregiver burden menggunakan Zarit Burden Interview (ZBI). Analisis menggunakan Poisson Regression untuk mengestemasi nilai Prevalence Rasio (PR). Hasil: Hasil penelitian menunjukkan bahwa terdapat 40.78\% caregiver yang mengalami burden. Pasien yang
}

ketergantungan total (PR 1.86; 95\% CI 1.021-3.377), berat (PR 1.77; 95\% CI 1.026-3.068), sedang (PR 2.08; 95\% CI 1.167-3.710) dan durasi merawat pasien $>6$ jam/hari merupakan faktor yang signifikan memengaruhi caregiver burden pada pengasuh utama pasien stroke. Simpulan: Caregiver burden dipengaruhi oleh kondisi pasien dan kondisi dalam merawat pasien. Perlunya edukasi terkait home care pada caregiver sebelum pasien keluar dari rumah sakit. Dan perlu dilakukan konsultasi berkala pada caregiver.

Kata kunci: beban pengasuh; pasien stroke; home care

\section{PUSTAKA}

1. Dinas Kesehatan Republik Indonesia. Riset Kesehatan Dasar 2013. pp. 111-116, 2013.

2. Bidang P2 Dinas Kesehatan Kabupaten Wonogiri. Laporan surveilans Penyakit tidak menular kabupaten Wonogiri,” 2015.

3. Gbiri CA, Olawale OA, Isaac SO. Stroke management: Informal caregivers' burdens and strians of caring for stroke survivors. Annals of physical and rehabilitation medicine. 2015 Apr 1;58(2):98-103.

4. Morimoto T, Schreiner AS, Asano H. Caregiver burden and health-related quality of life among Japanese stroke caregivers. Age and Ageing. 2003 Mar 1;32(2):218-23.

5. Jaracz K, Grabowska-Fudala B, Górna K, Jaracz J, Moczko J, Kozubski W. Burden in caregivers of long-term stroke survivors: Prevalence and determinants at 6 months and 5 years after stroke. Patient education and counseling. 2015 Aug 1;98(8):1011-6.

6. Ogunlana MO, Dada OO, Oyewo OS, Odole AC, Ogunsan MO. Quality of life and burden of informal caregivers of stroke survivors. Hong Kong Physiotherapy Journal. 2014 Jun 1;32(1):6-12.

7. Choi-Kwon S, Kim HS, Kwon SU, Kim JS. Factors affecting the burden on caregivers of stroke survivors in South Korea. Archives of physical medicine and rehabilitation. 2005 May 1;86(5):1043-8.

8. McCullagh E, Brigstocke G, Donaldson N, Kalra L. Determinants of caregiving burden and quality of life in caregivers of stroke patients. Stroke. 2005 Oct 1;36(10):2181-6.

9. Gbiri CA, Olawale OA, Isaac SO. Stroke management: Informal caregivers' burdens and strians of caring for stroke survivors. Annals of physical and rehabilitation medicine. 2015 Apr 1;58(2):98-103.

10. Bhattacharjee M, Vairale J, Gawali K, Dalal PM. Factors affecting burden on caregivers of stroke survivors: Population-based study in Mumbai (India). Annals of Indian Academy of Neurology. 2012 Apr;15(2):113. 